\title{
I'TIBĀR AL MA'ALAT PRINCIPLES IN MUI FATWA NUMBER 14 OF 2020 CONCERNING ORGANIZATIONS OF WORSHIP IN SITUATIONS OF THE COVID-19 \\ OUTBREAK
}

Oleh: Islamul Haq ${ }^{1}$, Abdul Syatar2, M Ali Rusdi Bedong'3, Muhammad Haramain ${ }^{4}$ E-mail: islamulhaq@iainpare.ac.id, abdulsyatar@gmail.com,malirusdi@iainpare.ac.id,

Muhammmadharamain@iainpare.ac.id

1,3,4IAIN Parepare, 2 UIN Alauddin Makassar

\begin{abstract}
This study aims at examining the use the principle of $i$ tibar al ma'alat in the MUI fatwa number 14 of 2020 concerning the organization of worship in situations of the Covid-19 outbreak. MUI fatwa number 14 of 2020 forced most Muslims in Indonesia to worship out of the box. the results of the study it was found that the MUI in issuing fatwa number 14 of 2020 had considered the principle of i'tibar al ma'alat, the prohibition of worshiping in congregation in areas with high distribution potential was determined in order to anticipate the spread of the Covid-19 outbreak. However, the MUI does not generalize all regions, this is also done based on the principle of $i^{\prime}$ tibar al ma'alat to avoid the practice of tafrith to religious orders in the midst of society.
\end{abstract}

Keywords: I'tibar al Ma'alat, Covid-19, Fatwa MUI

\section{INTRODUCTION}

Beginning in 2020, the world was shocked by the COVID-19 outbreak which quickly spread to almost the entire world. Since January 2020, WHO has stated that this virus has entered a global emergency ${ }^{1}$. This virus has an impact on all sectors, ranging from the economic, security, socio-cultural sectors to the religious sector of human life. a series of large-scale events had to be postponed even if not a few were canceled to anticipate the spread of COVID-19. Delays or cancellations of large events due to these events will bring hundreds or even thousands of visitors ${ }^{2}$. The Indonesian government has also canceled several

\footnotetext{
${ }^{1}$ Dana Riksa Buana, "Analisis Perilaku Masyarakat Indonesia Dalam Menghadapi Pandemi Virus Corona (Covid-19) Dan Kiat Menjaga Kesejahteraan Jiwa," SALAM: Jurnal Sosial Dan Budaya Syar-I 7, no. 3 (2020), h. 218.

2 Deutsche Welle, “Deretan Perhelatan Dunia Yang Batal Karena Virus Corona," Detik.Com, 2020, https://news.detik.com/dw/d-4933984/deretan-perhelatan-dunia-yang-batal-karena-viruscorona.
} 
major events and issued a state of disaster emergency related to the COVID-19 epidemic ${ }^{3}$.

The religious life of humankind became one of the sectors most affected by this COVID-19 pandemic. Some places of worship such as mosques, churches, temples have changed the way of worship to break the chain of distribution of COVID-19. Indonesian people, who are predominantly Muslim, who usually worship with the standards they used to do are forced to worship out of the box. Not a few who are confused about kayfiyat or the procedure for conducting worship in this COVID-19 period. In Islam, especially the prayer has a rule, a patent procedure so that a person may not do ijithad in this realm. The Shari'a have established legal requirements, in harmony with the things that can cancel the prayers. Although in certain circumstances, these provisions may change when faced with an emergency or some benefits demand $i^{4}$.

This pandemic has influenced Islamic religious perspectives and strategies in regulating how Muslims carry out their worship in the mosque. This pandemic also forced the ulama to issue a new fatwa on the procedure for worship during the COVID-19 period 5 . In the end, scholars have to hack new fiqh related to the coronavirus.

The Indonesian Ulema Council as an institution tasked with assisting the government in matters relating to a public record has issued a fatwa number 14 of 2020 concerning organizing worship in situations of co-19 epidemics. Among the provisions of the fatwa law states that:

a. "People who have been exposed to the Coronavirus, must protect and isolate themselves so that transmission does not occur to others. For him, Friday prayers can be replaced with Zuhr prayers, because Friday prayers are compulsory worship that involves many people, so there is a chance of mass transmission of the virus. For him, it is forbidden to carry out sunnah worship activities that open up opportunities for transmission, such as congregational prayers five times / rawatib, Tarawih and Eid prayers in mosques or other public places, as well as attending public recitals and large tablighs "

b. "In the case that he is in an area with high or very high transmission potential based on the provisions of the authorities, he may leave Friday prayers and replace them with the midday prayer at the residence, and leave the congregation to pray five times / rawatib, Tarawih, and EED at the mosque or other public places. "

\footnotetext{
${ }^{3}$ Nograhany Widhi Koesmawardhani, "Pemerintah Tetapkan Masa Darurat Bencana Corona Hingga 29 Mei 2020," Detik.Com, 2020, https://news.detik.com/berita/d-4942327/pemerintahtetapkan-masa-darurat-bencana-corona-hingga-29-mei-2020.

${ }^{4}$ Syandri Syandri and Fadhlan Akbar, "Penggunaan Masker Penutup Wajah Saat Salat Sebagai Langkah Pencegahan Wabah Coronavirus Covid-19," SALAM: Jurnal Sosial Dan Budaya Syar-I 7, no. 3 (2020), h. 262.

${ }^{5}$ Faried F Saenong etl., Fikih Pandemi Beribadah Di Masa Wabah (Jakarta: NUO Publishing, 2020).
} 
c. "If he is in an area where the potential for transmission is low based on the provisions of the authorities, he is still obliged to carry out religious duties as usual and must guard himself against being exposed to COVID-19, such as not having direct physical contact (shaking, hugging, kissing hands) bring your prayer mat, and often wash your hands with soap ".

d. "In a condition where the spread of COVID-19 is uncontrolled in a lifethreatening region, Muslims must not hold Friday prayers in that area, until conditions return to normal and must replace them with zuhr prayers in their respective places. Likewise, it is not permissible to carry out religious activities that involve large numbers of people and is believed to be the media for the spread of COVID-19, such as the five-time congregation prayers, Tarawih and Eid prayers in mosques or other public places, as well as attending general recitals and taklim assemblies.

e. "In a condition where the spread of COVID-19 is controlled, Muslims are obliged to hold Friday prayers and may hold worship activities that involve many people, such as pilgrims to pray five times / rawatib, Tarawih and Eid prayers in mosques or other public places, as well as attend public recitals and assemblies taklim while keeping yourself from being exposed to COVID-19"6.

According to the author, MUI fatwa number 14 of 2020 is very moderate and accommodating. This MUI fatwa has also used various approaches in Islamic law, both the nash approach, the hajjy approach and the qauly approach.7. This can be seen from the first page to page 7 of this fatwa mentions some texts (the Koran and Hadith), qawaid al fighiyah, and opinions of scholars related to the implementation of worship in abnormal times. But in reality, many Muslims who gave a negative response to this MUI fatwa. they did not heed the MUI fatwa to worship at home to break the chain of the spread of the coronavirus. Some of them think that COVID-19 is not as dangerous as what is described in various media, they are not afraid to do activities outside the home or activities that involve many people because they believe that the corona is not as dangerous as described, they do not heed the MUI fatwa and the government appealed because they felt they understood more and understood better the current conditions even though it was a mistake 8 .

Based on the background above, the researcher intends to research the I'tibār Al Ma'alat Principle in the MUI Fatwa No. 14 of 2020 concerning Organizing Worship in Situations of the Covid-19 Outbreak.

\footnotetext{
${ }^{6}$ Majlis Ulama Indonesia, FATWA MAJELIS ULAMA INDONESIA Nomor: 14 Tahun 2020 Tentang PENYELENGGARAN IBADAH DALAM SITUASI TERJADI WABAH COVID-19, 14 (Indonesia, issued 2020).

${ }^{7}$ Heri Fadli Wahyudi and Fajar Fajar, "Metode Ijtihad Komisi Fatwa Majelis Ulama Indonesia Dan Aplikasinya Dalam Fatwa," Cakrawala: Jurnal Studi Islam 13, no. 2 (2018): 120-33.

8 Buana, "Analisis Perilaku Masyarakat Indonesia Dalam Menghadapi Pandemi Virus Corona (Covid-19) Dan Kiat Menjaga Kesejahteraan Jiwa."
} 


\section{METHOD}

The data in this study are divided into two, namely primary data and secondary data. Primary data in this study were obtained through direct observation and interviews with the subject, as for the secondary data in this study in the form of books, journals, and several articles related to the object of the problem under study.

\section{RESULT \& DISCUSSION}

\section{A. The principle of $i^{\prime} t i b \bar{a} r$ al-Māàlāt in Islamic Law}

I'tibār al-Maālāt consists of two syllables namely the word i'tbar which in Arabic means to assume, reckon, consider, and the word al maalat which means the end or last place. In the context of this article is interpreted as an impact. As for the term definition of $i^{\prime}$ tibār al-Maālāt according to Mahmud Hamid Usman is observing and considering the impact when taking action and deciding what to do'. According to Farid Al Anshari i'tibār al-Maālāt is a general principle which is like a consideration of the consequences of the law that will be enforced ${ }^{10}$. Walid bin Ali Al Husain defines i'tibār al-Maālāt as a consideration of the impact that will occur in the application of law following the sharia maqashid ${ }^{11}$. Based on the understanding that has been mentioned by the scholars, then the meaning of i tibār al-Maālāt is a consideration of the impact that will be caused by the legal act of the Mukallaf and or a legal decision on legal actions or events ${ }^{12}$.

The principle of i'tibār al-Maālāt is a legal approach in the Shari'a. This principle has existed since the start of Islamic da'wah in the Mecca period when the Messenger of Allah. detain his friends to repay the wrongdoing of Quraiys infidels by considering the condition of Muslims who are still weak and consideration of the bad consequences that will arise if his friends are not able to hold back. This is a form of the i tibār al-Maālāt approach of the Messenger of Allah. The application of the principle of i tibār al-Maālāt is also found in al Quran such as when Allah forbade Adam to eat the fruit in heaven, Allah says in Surah Al Baqarah verse 35:

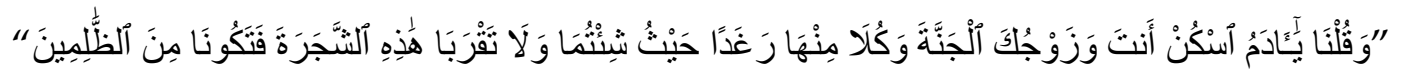

Translation: "And We say:" O Adam, be taken care of by you and your wife of

\footnotetext{
${ }_{9}^{9}$ Mahmud Hamid Usman, Qaidah Sadd Al Zaraiy (Dar Al Hadist, 2001), h. 212.

${ }^{10}$ Farid Al Anshari, Al Mushtalah Al Ushuly 'Inda As Syathibi (Dar Al Najah AL Jadid, 2004), h. 428. ${ }^{11}$ Walid bin Ali Al Husain, I'tibar Al Maalat Wa Atsaruha Fi Al Figh (Dar Al Tadmiriyyah, 2008) h. 37.

12 Abd Rauf Amin, "Prinsip 'I 'Tibār Al-Maālāt' Dan 'Murā 'Āt Al-Khushūshiyāt' Dan Kontribusinya Bagi Keberlangsungan Ummah: Sebuah Kajian Maqasid Al-Syariah," Journal of Techno Social 10, no. 2 (2018) h. 30.
} 
this paradise, and eat many more good foods wherever you like, and do not approach this tree, which causes you to be among those who do wrong ".

The prohibition to approach the tree in the above verse is one form of itibar al ma'alaat. Then the prohibition on the Messenger of Allah. to answer the sound in prayer to avoid the attack of the polytheists when they hear the recitation of the Prophet. Allah says in Surah Al Isra verse 110:

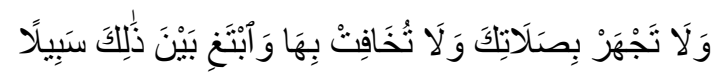

Translation: "And do not raise your voice in your prayer and do not lower it nor seek a middle ground between the two".

The principle of i tibār al-Maālät is also found in many of the hadiths of the Muhammad Prophet. as when the Prophet was about to complete the building of the Kaaba he held back the ego to build the Kaaba according to the foundation that had been built by the Prophet Ibrahim as, he was willing to change the position of the Kaaba as when the Prophet Ibrahim built the Kaaba in the interests of the wider community. The Prophet said to Ayesha: "O Ayesha, if it were not for your people who had just left jahiliyah, I would have ordered them to destroy the Ka'bah, I would have built them according to the foundations which Ibrahim built ${ }^{13}$." The Prophet in this case prevented him from building the Ka'bah according to the foundation of the prophet Ibrahhim. to avoid conflict from the polytheists.

in another hadith the Messenger of Allah. said:

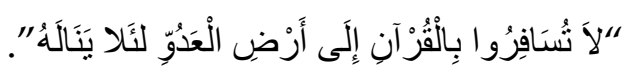

Meaning: "Do not you travel to enemy territory with the Koran, so that the enemy does not take it"14

Prohibition of the Messenger of Allah. to travel to the enemy's territory by bringing the Koran is his form of i tibār al-Maālāt by the context at that time.

The ulama have also coined several fiqh rules regarding i tibār al-Maālāt including the rules المنوقع كالواقع (1) (predictions about the impact that will arise as well as reality), الضرر في المآل ينزل منزلة الحرر (2) udar then occupy the position of harm that exists today) (2) الأمور بعو اقبعال فئر (everything depends on its impact).

Based on the principle of $i$ tibar al ma'alaat, a mufti or mujtahid must consider the impact that will result from the enactment of the law, predict the possibilities of good or bad from the fatwa that he gave birth to and do not assume that the duty of a mufti is merely establishing the law. But a mujtahid/mufti has to

${ }^{13}$ Imam Al-Bukhari, "Shahih Bukhari,” Daar Al-Fikr, 1987.

${ }^{14}$ Imam Muslim, “Shahih Muslim,” Beirut: Darul Fikr. Jilid V, 1992. 
consider the impact that will arise from a legal decision and determine the law for an event ${ }^{15}$.

Seeing the consequences of legal action is a form of Sharia objectives, whether the action is following the Shari'a or not. A mujtahid or mufti will not establish a law before considering the consequences that will result from the stipulation of the law. This kind of ijtihad requires special expertise in a mujtahid. A mujtahid is considered insufficient if only a jurist is proficient in sharia texts in detail but he is also required to be proficient in the characteristics and secrets of human psychology and social sciences ${ }^{16}$.

To understand the principle of I'tibār al-Maālāt there are two key words namely al iqtidha al ashly or called the primary law and al iqtidha at tab'iy or secondary law. The primary law is syariah law 'which is stipulated in normal situations or conditions and secondary law is a law that is set syara' under abnormal conditions. The act of believer can be in normal conditions can bring benefit but in abnormal conditions, it can be that the actions bring harm. Therefore, a mujtahid/mufti is always required to ensure the suitability of the law given to legal subjects after researching the conditions or cases of the intended law ${ }^{17}$.

Ibn al-Qayyim decided that "a mufti and ruler may not issue fatwas or rules unless he understands two things, namely understanding reality and understanding the obligations contained in reality". What Ibnu Qayyim understood by understanding the obligations contained in reality was understanding the impact that would arise from the application of the law ${ }^{18}$.

In another context, Islamic law has another approach similar to I'tibār alMaālāt namely the Istihsān and Sadd al-Dzarì'ah approaches. Having carefully listened to the essence and concept of both, it can be said that they are the result of the principle of I'tibār al-Maālāt ${ }^{19}$. I'tibār al-Maālāt is a legal principle while Istihsān and Sadd al-Dzarî'ah are legal methods. However, the three are synergistic theories and can be used by scholars to improve, make legal innovations for the realization of human benefits that can guarantee its sustainability ${ }^{20}$.

\footnotetext{
${ }^{15}$ Moh Toriquddin, "Teori Maqashid Syari'ah Perspektif Al-Syatibi," De Jure: Jurnal Hukum Dan Syar'iah 6, no. 1 (2014) h. 46.

${ }^{16}$ Ahmad Al Raisuni, Nadariyât Al-Maqâshid „Inda Al-Imâm Al-Shâthibi (Bairut: Muassasah Al Jamiah, 1992) h.311.

${ }_{17}$ Amin, "Prinsip 'I 'Tibār Al-Maālāt' Dan 'Murā 'Āt Al-Khushūshiyāt' Dan Kontribusinya Bagi Keberlangsungan Ummah: Sebuah Kajian Maqasid Al-Syariah.” H. 32.

${ }^{18}$ Abdullah bin Beh, Tanbih Al Maraji' Ala Ta'shil Figh Al Waqi' (Abu Dhabi: Markaz Al Muwattha' li Ad Dirasah wa Al Ta'lim, 2017). H. 57.

19 Islamul Haq, “(العلاقة السبية في جريمة القتل (دراسة لغوية وحكمية), Langkawi: Journal of The Association for Arabic and English 2, no. 1 (2016): 136-52.

${ }^{20}$ Amin, "Prinsip 'I 'Tibār Al-Maālāt' Dan 'Murā 'Āt Al-Khushūshiyāt' Dan Kontribusinya Bagi

Keberlangsungan Ummah: Sebuah Kajian Maqasid Al-Syariah.” H. 32.
} 


\section{B. The Principle of I'tibar Al Ma'alat in the MUI Fatwa Number 14 of 2020}

MUI Fatwa Law provisions No. 14 of 2020 regarding the conduct of worship in situations of the COVID-19 outbreak stipulate that: "People who have been exposed to the Coronavirus, must protect and isolate themselves and are haram to conduct worship activities in the congregation in the mosque, an area with a high potential for transmission. or very high and the area where the spread of COVID-19 can not be controlled may leave Friday prayers and replace them with Zuhr prayers at the residence, and leave the congregation to pray five times/rawatib, Tarawih, and EED in mosques or other public places"21. his MUI fatwa is tiered by considering the severity of an area.

This fatwa was issued by MUI based on several considerations, namely: the spread of COVID-19 outbreaks to various countries including Indonesia, the determination of the world health organization (WHO) that made COVID-19 a pandemic, the need to take religious measures to break the chain of COVID-19 distribution, the importance of establishing fatwas on the organization of worship in situations where the plague-19 outbreak occurred to later be used as a guideline in setting COVID-19 countermeasures policies related to religious matters.

Through this fatwa it is understood that there is conditionality related to person and conditionality related to the region. A person in a positive condition is affected by the COVID-19 virus, so he must not be in a public community, including for public worship purposes to prevent the widespread transmission of COVID-19. While people who are still in good health and are in areas that do not have the potential to call for COVID-19, the obligation to worship such as Friday prayers must be carried out with due regard to health protocols 22 .

This fatwa does not generalize all areas not to carry out worship that involves many people. Areas that do not have the potential for transmission are still obliged to carry out worship in the mosque, this is determined to prevent the occurrence of tafrith (disparaging or easy in religious matters) which is prohibited in the Shari'a.

In my opinion, the fatwa issued by the MUI has considered the principle of I'tibār al-Maālät. The prohibition to worship in the congregation for people who are positive COVID-19 or people who are in areas that have the potential to spread COVID-19 and the level of spread is out of control, is a fatwa that adheres to the principle of I'tibār al-Maālāt. MUI has considered the negative impact that will be caused when allowing positive patients to continue to worship in the congregation. Similarly, the negative impact that will arise when allowing mosques located in the red zone to continue to hold worship that involves many

${ }^{21}$ Majlis Ulama Indonesia, FATWA MAJELIS ULAMA INDONESIA Nomor: 14 Tahun 2020 Tentang PENYELENGGARAN IBADAH DALAM SITUASI TERJADI WABAH COVID-19. H. 8-9. ${ }^{22}$ Farih Maulana Sidik, "MUI: Ada Masyarakat Salah Paham Tentang Fatwa Ibadah Di Tengah Corona," 2020, https://news.detik.com/berita/d-4945228/mui-ada-masyarakat-salah-pahamtentang-fatwa-ibadah-di-tengah-corona. 
people. The spread of the virus will be increasingly difficult to control given the ease of spread of this COVID-19.

The MUI decree which does not generalize all regions is based on the principle of fiqh that says: "al hukmu yaduru ma'a illatihi wujud wa adaman" means that in realizing or nullifying the law depends on the illatnya. When there is no legal background in an area, the law does not apply in that area. This decree too. is a provision that considers the principle of I'tibār al-Maālāt. When the entire region is generalized to not carry out worship activities in the congregation, then in the future, it could be that people behave in a tafrith in similar cases with different contexts.

\section{CONCLUSION}

The Principle of I'tibār al-Maālāt is one of the general principles of jihad/piety in Islamic law. a mufti or mujtahid must consider the impact that will result from the enforcement of the law and predict the possibilities of good or bad from the fatwa that he gave birth to. MUI Fatwa No. 14 of 2020 regarding the holding of worship in situations where the plague COVID-19 has already been based on the principle of I'tibār al-Maālāt. MUI stipulates the prohibition to conduct worship activities in the congregation in the mosque for positive communities and areas with high potential for spreading the virus based on consideration of the ease of spread of COVID-19 and the danger that this virus will cause. MUI does not generalize all regions in stipulating the prohibition to conduct worship activities in the congregation in the mosque, based on considerations to prevent the occurrence of tafrith attitude in religion in the community.

\section{BIBLIOGRAPHY}

Ahmad Al Raisuni. Nadariyât Al-Maqâshid "Inda Al-Imâm Al-Shâthibi. Bairut: Muassasah Al Jamiah, 1992.

Al-Bukhari, Imam. "Shahih Bukhari Juz I." Daar Al-Fikr, 1987.

Amin, Abd Rauf. "Prinsip 'I 'Tibār Al-Maālāt' Dan 'Murā 'Āt Al-Khushūshiyāt' Dan Kontribusinya Bagi Keberlangsungan Ummah: Sebuah Kajian Maqasid Al-Syariah." Journal of Techno Social 10, no. 2 (2018).

Beh, Abdullah bin. Tanbih Al Maraji' Ala Ta'shil Figh Al Waqi'. Abu Dhabi: Markaz Al Muwattha' li Ad Dirasah wa Al Ta'lim, 2017.

Buana, Dana Riksa. "Analisis Perilaku Masyarakat Indonesia Dalam Menghadapi Pandemi Virus Corona (Covid-19) Dan Kiat Menjaga Kesejahteraan Jiwa." SALAM: Jurnal Sosial Dan Budaya Syar-I 7, no. 3 (2020).

Farid Al Anshari. Al Mushtalah Al Ushuly 'Inda As Syathibi. Dar Al Najah AL Jadid, 2004.

Faried F Saenong dkk. Fikih Pandemi Beribadah Di Masa Wabah. Jakarta: NUO Publishing, 2020. 
Haq, Islamul. "(العلاقة السبيية في جريمة التنل (دراسة لغوية وحكمية)." Langkawi: Journal of The Association for Arabic and English 2, no. 1 (2016): 136-52.

Husain, Walid bin Ali Al. I'tibar Al Maalat Wa Atsaruha Fi Al Figh. Dar Al Tadmiriyyah, 2008.

Koesmawardhani, Nograhany Widhi. "Pemerintah Tetapkan Masa Darurat Bencana Corona Hingga 29 Mei 2020." Detik.Com, 2020. https:/ / news.detik.com/berita/d-4942327/ pemerintah-tetapkan-masadarurat-bencana-corona-hingga-29-mei-2020.

Majlis Ulama Indonesia. FATWA MAJELIS ULAMA INDONESIA Nomor: 14 Tahun 2020 Tentang PENYELENGGARAN IBADAH DALAM SITUASI TERJADI WABAH COVID-19. 14. Indonesia, issued 2020.

Muslim, Imam. "Shahih Muslim." Beirut: Darul Fikr. Jilid V, 1992.

Sidik, Farih Maulana. "MUI: Ada Masyarakat Salah Paham Tentang Fatwa Ibadah Di Tengah Corona," 2020. https://news.detik.com/berita/d4945228/ mui-ada-masyarakat-salah-paham-tentang-fatwa-ibadah-ditengah-corona.

Syandri, Syandri, and Fadhlan Akbar. "Penggunaan Masker Penutup Wajah Saat Salat Sebagai Langkah Pencegahan Wabah Coronavirus Covid-19." SALAM: Jurnal Sosial Dan Budaya Syar-I 7, no. 3 (2020).

Toriquddin, Moh. "Teori Maqashid Syari'ah Perspektif Al-Syatibi." De Jure: Jurnal Hukum Dan Syar'iah 6, no. 1 (2014).

Usman, Mahmud Hamid. Qaidah Sadd Al Zaraiy. Dar Al Hadist, 2001.

Wahyudi, Heri Fadli, and Fajar Fajar. "Metode Ijtihad Komisi Fatwa Majelis Ulama Indonesia Dan Aplikasinya Dalam Fatwa." Cakrawala: Jurnal Studi Islam 13, no. 2 (2018): 120-33.

Welle, Deutsche. "Deretan Perhelatan Dunia Yang Batal Karena Virus Corona." Detik.Com, 2020. https://news.detik.com/dw/d-4933984/deretanperhelatan-dunia-yang-batal-karena-virus-corona. 